Kocaeli Journal of Science and Engineering

\title{
Knowledge and Behaviors of Industrial Radiography Workers about Radiation Protection
}

\author{
Abdulkadir YILDIZ ${ }^{1, *}$ (D), Hakan PEKEY ${ }^{2}$ (D) \\ ${ }^{1}$ Department of Occupational Health and Safety, Kocaeli University, Kocaeli, 41310, Turkey, ORCID: 0000-0002-9098-7667 \\ ${ }^{2}$ Department of Environmental Engineering, Kocaeli University, Kocaeli, 41310, Turkey, ORCID: 0000-0002-6135-7770
}

\section{Article Info}

Research paper

Received : January 24, 2019

Accepted : August 28, 2019

\section{Keywords}

Industrial Radiography

Occupational Health and Safety

Radiation Protection

Radiography Workers'Behavior

\begin{abstract}
In our day, radiation sources have been used for useful purposes in industrial fields, but unrestrained and unconscious usage of radiation sources can be fatal. In this study, a survey has been shared online with 65 industrial radiography workers in order to assess their knowledge and behaviors towards radiation protection. The Cronbach's alpha coefficient of 0.85 demonstrated good reliability of the questionnaire. Of the participants, $53.8 \%$ had high school diploma and $29.2 \%$ had bachelor's degree. The majority of workers $(98.5 \%)$ was male and $43 \%$ of them had 11 years and more experience. The maximum percentages of industrial radiography workers' knowledge about radiation safety basic concepts such as three basic principles of radiation protection, collimator, dosimeter usage in working condition A and effective dose were 95.4\%, 93.9\%, 93.8\% and 90.8\%, respectively. 65 participants $(100 \%)$ agreed the definition as "I check radiography device and auxiliary equipment before the work commences". $98.4 \%$ of the workers stated that they restricted the working area by using radiation warning signs and flashlights during the radiographic test. While working with radioactive sources, personnel must wear special PPE (Personal Protective Equipment) such as; lead gloves, lead glasses, lead apron, gonad and thyroid protection equipment etc. $57 \%$ of radiographers (37) stated that they have been using the special PPE's during the work. About $40 \%$ of responding workers (24) stated that they have not been using and 3\% of them (4) stated that they have no idea about the usage of special PPE. Finally, survey results indicated that most of the radiographers who are occupationally exposed to radiation have a good knowledge and behaviors. However, some of them need to be trained about special radiation PPE usage.
\end{abstract}

\section{Introduction}

Radiation is the process by which energy is emitted as either particles or waves. Sources of radiations may be natural as well as man-made. The natural radiation sources originate from uranium and thorium series, from potassium-40 and from the interaction of cosmic radiation with matter, while man-made radiation sources include various applications used in medicine, consumer products, nuclear weapon and industries [1,2].

A major industrial application of radiation is the use of radiography for the non-destructive testing, and it provides a means of verifying the physical integrity of equipment and structures such as vessels, pipes, welded joints etc. Industrial radiography work poses a negligible risk if it is performed in a safe manner. Persons performing industrial radiography work are responsible for ensuring that their work is carried out safely and in compliance with all relevant regulations and safety requirements [3]. However, throughout the history of industrial radiography, accidents have occurred that have resulted in high doses to workers, causing severe health consequences such as radiation burns and, in a few cases, death due to malfunctioning of the radiography devices or its several components [4].

Radiography device consists of mechanical components such as sealed source, guide tube, control cable and collimator etc. as shown in Figure 1 [5].

\footnotetext{
* Corresponding Author: kyldz88@ gmail.com
} 


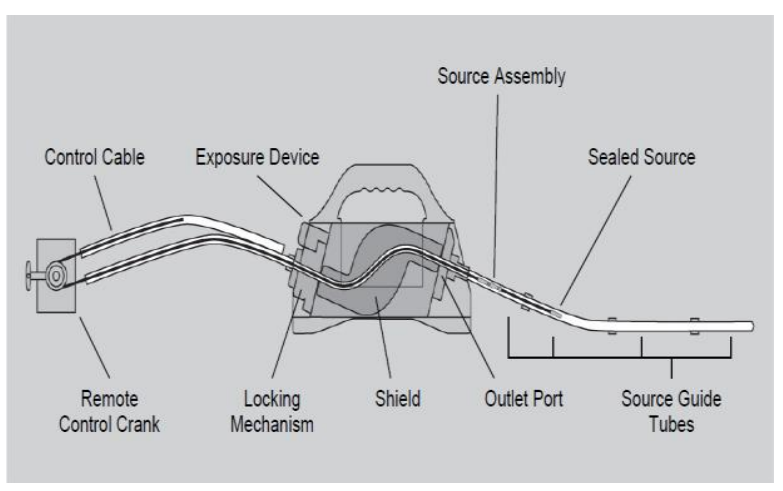

Figure 1. Radiography device and its components.

It is very important to ensure that these devices are designed, manufactured and tested to meet the requirements of ISO 3999 or equivalent national requirements [6].

Radiography processes are made by sending the radiation source which is trapped in a pigtail holder towards the collimator to guide tube with control cable tied to a geared system and that source is replaced back to its secure position after the end of the work. The collimator is shielding material that can direct radiation beam in different angles and used for limiting the radiation zone occurred due to radiation source [7]. After equipment is ready for use, warning alarms are given prior to work and during exposure of the source, dose rate meter is used to monitor the working place [8].

Occupational radiation protection is a necessity during industrial radiography works. The following basic principles are implemented to protect people against radiation:

- Time: Activities which are carried out by using radiation sources to be completed as soon as possible.

- Distance: By taking that radiation dose rate decreases inversely proportional with the square of the distance into consideration adequate distance shall be provided from the radiation sources or from the equipment's including sources.

- Shielding: In case the time and distance principles are not enough to decrease the dose exposing then the operations shall be performed between the blocks made of dense materials with highly absorption feature such as lead or concrete [7].

ICRP (International Commission on Radiological Protection) provides recommendations and guidance on protection against the risks associated with ionizing radiation, from artificial and naturally occurring sources. The ICRP began to develop the risk/benefit concept since 1977. This concept has three key principles of radiation protection which are justification, optimization by following ALARA "As Low as Reasonably Achievable" principle and dose limitation. Occupational doses are limited to $50 \mathrm{mSv}$ per year, whereas exposures to the general public are limited to $1 \mathrm{mSv}$ per year [9].

Special Radiation PPE's (Personal Protective Equipment) such as lead apron, lead gloves and sleeves, lead goggles, gonad shield and thyroid shield should be used by radiography workers to provide protection against actual or potential exposure to ionizing radiation [10].

In case of emergency or accident during industrial radiography works carry out, required intervention should be done by following Emergency Response Plan prepared by license holder. After the accident or end of the emergency situation, radiation doses of radiation workers and others exposed to and body intake way of the radioactive materials and cause shall be investigated by the license holder or a person charged with investigation by license holder and result shall be reported to the Authority as soon as possible together with the film and/or TLD dosimeter and if necessary also with chromosome aberration test results of the radiation workers [11].

\section{Materials and Methods}

The aim of this study is to gather information regarding knowledge and behaviors of industrial radiography workers about radiation protection.

For this purpose this survey has been applied as a data collection method and the application was made by electronic mail after getting the Kocaeli University Research Ethics Committee Approval. 65 radiographers who work at private company in Turkey have been participated in this survey.

18 survey items which are developed by authors have been included in data collection form. The first 5 questions are related to socio-demographic information of workers and the following 13 questions are related to radiation protection culture of the radiographers in Oil and Gas Industry.

Statistical analysis was performed using the Statistical Program for Social Sciences (SPSS) version 22 (IBM Corp. New York, USA). The Cronbach's alpha was established to assess internal reliability. The internal reliability of the questionnaire was reflected in the Cronbach's alpha reliability coefficient of the whole questionnaire is 0.85 , the Cronbach's alpha coefficient of all factors is $0.74-0.83$ ( $\mathrm{p}<0.05$ ). This exceeds the minimum criterion of 0.70 and indicates good reliability [12].

The socio-demographic characteristics of participants who completed survey items are given in Table 1. About $53.8 \%$ of the radiographers had high school diploma, about $13.8 \%$ had two-year degree, $29.2 \%$ 
bachelor's degree and 3.2\% had postgraduate degree.

Table 1. Socio-demographic characteristics of participants.

\begin{tabular}{|c|c|c|}
\hline & Frequency & $\begin{array}{c}\text { Percent } \\
(\%)\end{array}$ \\
\hline \multicolumn{3}{|l|}{ Gender } \\
\hline Male & 64 & 98.5 \\
\hline Female & 1 & 1.5 \\
\hline \multicolumn{3}{|l|}{ Age } \\
\hline $31-40$ years & 26 & 40 \\
\hline 21-30 years & 24 & 36.3 \\
\hline 40 and more & 15 & 23.7 \\
\hline \multicolumn{3}{|c|}{ Educational Background } \\
\hline High School & 35 & 53.8 \\
\hline Two-year Degree & 9 & 13.8 \\
\hline Bachelor's Degree & 19 & 29.2 \\
\hline Postgraduate & 2 & 3.2 \\
\hline \multicolumn{3}{|l|}{ Profession } \\
\hline Radiographer & 42 & 64.6 \\
\hline $\begin{array}{l}\text { Radiography } \\
\text { Co-worker }\end{array}$ & 7 & 10.8 \\
\hline $\begin{array}{l}\text { Radiation Protection } \\
\text { Adviser }\end{array}$ & 16 & 24.6 \\
\hline \multicolumn{3}{|l|}{ Experience } \\
\hline 1 year & 1 & 3.3 \\
\hline $1-5$ years & 21 & 30.7 \\
\hline $6-10$ years & 15 & 23 \\
\hline 11 years and more & 28 & 43 \\
\hline
\end{tabular}

\section{Results and Discussion}

The present study has illustrated that general knowledge and behavior related to radiation protection are sufficient among participants. The knowledge of industrial radiography workers about radiation protection basic concepts has summarized in Table 2 .

Table 2. Socio-demographic characteristics of participants.

\begin{tabular}{|c|c|c|c|}
\hline & $\begin{array}{l}\text { Workers' } \\
\text { Knowledge }\end{array}$ & Frequency & $\begin{array}{c}\text { Percent } \\
(\%)\end{array}$ \\
\hline \multirow{3}{*}{$\begin{array}{l}\text { Controlled } \\
\text { Area }\end{array}$} & Yes & 49 & 75.4 \\
\hline & No & 10 & 15.4 \\
\hline & Have No Idea & 6 & 9.2 \\
\hline \multirow{3}{*}{ Collimator } & Yes & 61 & 93.9 \\
\hline & No & 4 & 6.1 \\
\hline & Have No Idea & 0 & 0 \\
\hline \multirow{3}{*}{$\begin{array}{l}\text { Three Basic } \\
\text { Principles of } \\
\text { Radiation } \\
\text { Protection }\end{array}$} & Yes & 62 & 95.4 \\
\hline & No & 3 & 4.6 \\
\hline & Have No Idea & 0 & 0 \\
\hline \multirow{3}{*}{$\begin{array}{l}\text { ALARA } \\
\text { Principle }\end{array}$} & Yes & 58 & 87.7 \\
\hline & No & 2 & 3.1 \\
\hline & Have No Idea & 5 & 9.2 \\
\hline \multirow{3}{*}{$\begin{array}{l}\text { Effective } \\
\text { Dose }\end{array}$} & Yes & 59 & 90.8 \\
\hline & No & 1 & 1.5 \\
\hline & Have No Idea & 5 & 7.7 \\
\hline \multirow{3}{*}{$\begin{array}{l}\text { Dosimeter } \\
\text { Usage in } \\
\text { Working } \\
\text { Condition A }\end{array}$} & Yes & 61 & 93.8 \\
\hline & No & 0 & 0 \\
\hline & Have No Idea & 4 & 6.2 \\
\hline \multirow{3}{*}{$\begin{array}{l}\text { Dose } \\
\text { Limitation }\end{array}$} & Yes & 54 & 83.7 \\
\hline & No & 7 & 10.7 \\
\hline & Have No Idea & 4 & 5.6 \\
\hline
\end{tabular}

As it displays in the table above, the maximum percentages of industrial radiography workers' knowledge about radiation safety basic concepts such as three basic principles of radiation protection, collimator, dosimeter usage in working condition $\mathrm{A}$ and effective dose are $95.4 \%, 93.9 \%, 93.8 \%$ and $90.8 \%$, respectively.

About $75.4 \%$ (49) of the industrial radiography workers stated correctly that the Controlled Area is where workers might be exposed to radiation dose 3/10 more than the average annual dose limits of five consecutive years. 
58 responding radiographers $(87.7 \%)$ agreed, 2 participants $(3.1 \%)$ did not agree and 5 participants (9.2\%) had no idea about the definition "ALARA means As Low As Reasonably Achievable”.

54 participants $(83.7 \%)$ stated that they always tried to keep the receiving dose as low as reasonably achievable for all possible irradiations, 7 participants $(10.7 \%)$ who need to be educated and 4 participants (5.6\%) even had no idea about dose limitation that is one of the General Principle of Radiation Protection.

The behaviors of industrial radiography workers regarding radiation protection during radiography activities has summarized in Table 3 .

Table 3. The rate and percent of industrial radiography workers' behaviors about radiation protection.

\begin{tabular}{|c|c|c|c|}
\hline & $\begin{array}{l}\text { Workers' } \\
\text { Behaviors }\end{array}$ & Frequency & $\begin{array}{c}\text { Percent } \\
(\%)\end{array}$ \\
\hline \multirow{3}{*}{$\begin{array}{l}\text { Radiation } \\
\text { Measurement } \\
\text { on the } \\
\text { Radiography } \\
\text { Device }\end{array}$} & Yes & 51 & 78.5 \\
\hline & No & 9 & 13.8 \\
\hline & $\begin{array}{c}\text { Have No } \\
\text { Idea }\end{array}$ & 5 & 7.7 \\
\hline \multirow{3}{*}{$\begin{array}{l}\text { Dosimeter } \\
\text { Usage }\end{array}$} & Yes & 59 & 90.8 \\
\hline & No & 5 & 7.7 \\
\hline & $\begin{array}{c}\text { Have No } \\
\text { Idea }\end{array}$ & 1 & 1.5 \\
\hline \multirow{3}{*}{$\begin{array}{l}\text { Equipment } \\
\text { Control prior } \\
\text { to Work }\end{array}$} & Yes & 65 & 100 \\
\hline & No & 0 & 0 \\
\hline & $\begin{array}{c}\text { Have No } \\
\text { Idea }\end{array}$ & 0 & 0 \\
\hline \multirow{3}{*}{$\begin{array}{l}\text { Barricading } \\
\text { working area } \\
\text { with warning } \\
\text { signs }\end{array}$} & Yes & 64 & 98.4 \\
\hline & No & 1 & 1.6 \\
\hline & $\begin{array}{c}\text { Have No } \\
\text { Idea }\end{array}$ & 0 & 0 \\
\hline \multirow{3}{*}{$\begin{array}{l}\text { Special PPE } \\
\text { Usage }\end{array}$} & Yes & 37 & 56.9 \\
\hline & No & 24 & 36.9 \\
\hline & $\begin{array}{c}\text { Have No } \\
\text { Idea }\end{array}$ & 4 & 6.2 \\
\hline \multirow{3}{*}{$\begin{array}{l}\text { Emergency } \\
\text { Preparedness } \\
\text { and Response }\end{array}$} & Yes & 7 & 10.8 \\
\hline & No & 58 & 89.2 \\
\hline & $\begin{array}{c}\text { Have No } \\
\text { Idea }\end{array}$ & 0 & 0 \\
\hline
\end{tabular}

$78.5 \%$ (51) of the radiographers stated that they measured the radiation dose rate on the surface of radiography device before they work with ionizing radiation source. However, 13.8\% (9) of the workers did not measured the dose and $7.7 \%$ (5) of them had no any idea about dose rate measurement on the surface of the device.

The personal monitoring is crucial for radiographic testing. $90.8 \%$ (59) of the workers stated that they use dosimeter during working with ionizing radiation. $7.7 \%$ (5) of the workers stated that they do not use it and $1.5 \%$ (1) participant stated that have no idea about dosimeter. Almost $10 \%$ of the radiographers should not be allowed to work until they attend radiation safety training given by their Radiation Protection Adviser.

65 participants (100\%) agreed to definition as "I check radiography device and auxiliary equipment before the work commences". During the radiographic testing working area must be restricted by radiographer and radiation warning signs and flashlights must be put in place. 64 radiographers $(98.4 \%)$ stated that they implement these precautions before the work commence and only 1 participant (1.6\%) who need to be trained or not allowed to work with radiation sources stated that they do not implement.

While working with radioactive sources, personnel must wear special PPE (Personal Protective Equipment) such as; lead gloves, lead glasses, lead apron, gonad and thyroid protection equipment etc. $57 \%$ of radiographers (37) stated that they have been using the special PPE's during the work. About $40 \%$ of responding workers (24) stated that they have not been using and $3 \%$ of them (4) stated that they have no idea about usage of special PPE.

Radiation sources are potentially very hazardous and the role of the radiographer in an emergency is very crucial. In case of emergency or accident, workers should not leave the working place without informing responsible people such as Radiation Protection Adviser and put the radioactive source in safe (shielded) position. $89.2 \%$ of the radiographers (58) stated that they obey this rule in case of emergency. $10.8 \%$ of responding radiographers who need to be trained about emergency preparedness and response stated that they do not inform anybody and move away from the working area.

\section{Conclusions}

There is limited researching related to knowledge and behaviors of industrial radiography workers about radiation protection.

The findings from the present study demonstrated that the level of knowledge and behavior of industrial radiography workers who are occupationally exposed to radiation are adequate. 
Finally, besides to the majority of participants who have a good knowledge and behavior, the survey results indicated that some of them need to be educated about the hazards and risks of ionizing radiation and special PPE such as lead apron, lead gloves, safety goggles, gonad shield etc. usage and application of the basic radiation safety rules.

\section{References}

[1] International Atomic Energy Agency, 1999. Communications on Nuclear, Radiation, Transport and Waste Safety, Practical Handbook, IAEA(TECDOC-1076), Vienna.

[2] Hutchison S. G., Hutchison F. I., 1997. Radioactivity in Everyday Life. Journal of Chemical Education, 74, $501-505$.

[3] International Atomic Energy Agency, 2011. Radiation Safety in Industrial Radiography, Specific Safety Guide(SSG-11), Vienna.

[4] International Atomic Energy Agency, 1998. Lessons Learned From Accidents in Industrial Radiography, Safety Reports Series (No: 7), IAEA, Austria.

[5] Sentinel, 2015. 880 Delta Operating and Maintenance Manuel, QSA Global, http://www.qsaglobal.com/wp-content/uploads/2015/04/MAN-027. 2011.pdf

[6] International Organization for Standardization, 2004. Radiation Protection, Apparatus for Industrial Gamma Radiography, Specifications for Performance, Design and Tests, 2nd ed., Geneva.

[7] Official Gazette, 2005. Regulation on Radiation Protection and Licensing in Industrial Radiography, Number: 25869.

[8] Chamberlain D. A., Edney R., Bleakley G., 1996. Robotic Handling of Gamma-Ray Sources in Site Radiography of Steel Storage Tanks. Paper Presented at the 13th International Symposium on Automation and Robotics in Construction, Tokyo, Japan, 11-13 June, pp. 654.

[9] Members of the International Commission on Radiological Protection, 2007. Recommendations of the International Commission on Radiological Protection. Annals of the ICRP, Publication 103, Elsevier, Exeter.

[10] International Atomic Energy Agency, 2004. Personal Protective Equipment, Practical Radiation Technical Manual. IAEA, Vienna.
[11] Official Gazette, 2000. Regulation on Radiation Safety, Number: 23999.

[12] Nunnally J, Bernstein I, 1994. Psychometric Theory, 3rd ed., McGraw-Hill, New York. 